\title{
Benefits of Upper Limb Functional Electrical Stimulation in Children with Spastic Cerebral Palsy
}

\author{
Corina SPOREA ${ }^{1,2}$, Dumitru FERECHIDE ${ }^{1}$
}

\begin{abstract}
Aim: The aim of this study was to assess the effectiveness of Functional Electrical Stimulation in upper limb rehabilitation in children with cerebral palsy. Methods: 90 children with spastic cerebral palsy, age between 6 and 9 years, were randomized into two groups. 45 children, represented the control group, performed conventional physical and occupational therapy and robot-assisted therapy. In addition to the control group, the experimental group received functional electrical stimulation interventions with postural control on the affected upper limb. Results: The experimental group's motor performance after treatment (improved coordination by 8.2\%, wrist flexion by $9.75^{\circ}$, three-fingered grasp strength by $1.04^{\circ}$, and functional limitation lowered by 5.93) was considerably better than the control group's which coordination increased by $5.5 \%$, wrist flexion by $8.72^{\circ}$, three-fingered grasp strength by 0.7 and functional limitation decreased by 2.33. Conclusions: Functional electrical stimulation intervention was found to be an effective manner to improve motor performance, in terms of coordination, range of motion, and three-fingered grasp strength, visibly reducing functional limitation and improving performance in activities of daily living.
\end{abstract}

Keywords: cerebral palsy, functional electrical stimulation, upper limb rehabilitation.

\section{Rezumat}

Scop: Scopul acestui studiu a fost evaluarea eficacității stimulării electrice funcționale în recuperarea membrului superior la copii cu paralizie cerebrală. Metode: 90 de copii cu paralizie cerebrală spastică, cu vârsta cuprinsă între 6 și 9 ani, au fost împărțiți aleatoriu în două grupuri. 45 de copii, reprezentând grupul de control, au urmat ședințe de kinetoterapie, terapie ocupațională și recuperare robotizată. Suplimentar terapiei administrate grupului de control, grupul experimental a beneficiat de stimulare electrică funcțională însoțită de corecție posturală la nivelul membrului superior afectat. Rezultate: Performanța motorie în urma tratamentului în grupul experimental (îmbunătățirea coordonării cu 8,2\%, flexiei pumnului cu 9,75, forței pensei tridigitale cu 1,04 și reducerea limitării funcționale cu 5,93) a fost semnificativ mai bună decât în grupul de control, în care coordonarea a crescut cu $5,5 \%$, flexia pumnului cu $8,72^{\circ}$, forța pensei tridigitale cu 0,7 și limitarea funcțională a scăzut cu 2,33. Concluzii: Stimularea electrică funcțională s-a dovedit a fi o modalitate eficientă de a îmbunătăți performanța motorie în ceea ce privește coordonarea, amplitudinea de mișcare și forța pensei tridigitale, reducând vizibil limitarea funcțională și îmbunătățind performanța în activitățile cotidiene.

Cuvinte cheie: paralizie cerebrală, stimulare electrică funcțională, recuperarea membrului superior.

${ }^{1}$ "Carol Davila" University of Medicine and Pharmacy, Bucharest, Romania

2 „Dr. Nicolae Robanescu" National Clinical Center for Children Neurorehabilitation, Bucharest, Romania

\section{Corresponding author.}

Corina SPOREA, "Dr. Nicolae Robănescu" National Clinical Center

for Children Neurorehabilitation, Bucharest, Romania.

E-mail: corina.sporea@gmail.com 


\section{INTRODUCTION}

Cerebral palsy $(\mathrm{CP})$ is a group of permanent movement and posture disorders that are attributed to non-progressive disorders that occur during brain development in the fetal or infant period, which restricts activity, and are often accompanied by sensory disorders, perception, cognition, and musculoskeletal problems ${ }^{1}$. With a prevalence estimated range from 1.5 to 4.2 per 1,000 live births, according to recent population-based research from around the world ${ }^{2}, \mathrm{CP}$ is considered one of the most disabling conditions in childhood ${ }^{3}$.

Clinical forms of PC are characterized by motor and posture disorders, deficiencies of various types and intensities, which may be associated with involuntary movements and ataxic coordination disorders. The most common clinical form is spastic $\mathrm{CP}$ ( $\mathrm{SCP})$, which is found in over $86 \%$ of cases ${ }^{4}$. It occurs as a result of damage to the pyramidal system and is characterized by persistent, invariable hypertension, accentuated in the upper limbs on flexors and pronators and in the lower limbs on extensors and adductor muscles, accompanied by decreased muscle strength and motor deficit; stiffness and muscle atrophy secondary to inactivity; hyperreflexia; pathological reflexes (Babinski Sign) and clonus.

Upper limb tone and posture disorders specific SCP have a strong negative impact on hand functionality, decreased muscle strength, abnormal range of motion (ROM) and coordination deficits leading to a deterioration in quality of life (QoL) in children with $\mathrm{CP}$. The most frequent upper limb contracture patterns encountered in spastic $\mathrm{CP}$ are adduction and internal rotation of the shoulder, elbow flexion, forearm pronation, wrist flexion and clasp hand with thumb in palm ${ }^{5,6}$. Fine motor skills are performed with difficulty during gripping, pinching and grasping, thus affecting the ability to carry out the activities of daily living (ADLs) independently.

Rehabilitation in $\mathrm{CP}$ is a long process that aims to enhance functional independence, increase activity and improve participation in actions that prepare and facilitate the children's insertion in school and family environment.

Robot-Assisted Therapy (RAT) of the upper limb has the potential to lead to an increase in therapeutic performance due to its high accuracy, customized therapeutic programs (according to patient anthropometric characteristics and functioning limitations), audiovisual feedback, and virtual reality facilities.
Functional Electrical Stimulation (FES) used in clinical application as a "short-term treatment modality", until patients gain the ability to perform the functional activities independently, stimulates nerves and muscles imitating natural electrical brain signals.

The purpose of this study was to assess the effectiveness of FES combined with RAT and conventional physical therapy compared to RAT combined with conventional physical therapy in children with SCP. This comparison was performed in a single-blind randomized controlled trial.

\section{MATERIAL AND METHODS}

This study was approved by the CNCRNC ethics board. All parents voluntarily agreed to their children's participation in the study and gave written informed consent.

The study was conducted between 2017-2020, at CNCRNC on a group of 90 patients. The inclusion criteria were a history of SCP, age between 6 and 9 years, anthropometric characteristics compatible with RAT, an intelligence coefficient of IQ $\geq 55$ (ability to understand simple instructions) ${ }^{8}$, no significantly modified vision from the standard optotypic and spasticity MAS < 3 on Ashworth Modified Scale (increased muscle tone through most of the ROM, but able to move easily the affected part $)^{9,10}$. The exclusion criteria were severe mental or neurological disorders, unstable or inadequately consolidated fractures, osteoporosis (due to some precautions/apparatus limitations), sensory disorders that could prevent the reporting of possible pain, acute pain despite conventional pain treatment, apraxia or high degree of ataxia, skin lesions of the body parts in contact with the devices during training, inflammatory processes, and joint problems in the upper limb which, through repeated mobilizations during training, could lead to pain and irritation in the affected joints. In the FES group, there were 4 additional exclusion criteria: oncological pathology, seizure, pacemaker, and metal implants. The patients were equally randomized into 2 groups (1:1): an FES group and a control group. The control group $(n=45)$ received conventional physical and occupational therapy (PT and OT) and RAT for upper limbs. The FES group (the experimental one, $\mathrm{n}=45$ ) received, in addition to the control group, FES interventions with posture control on the affected upper limb. The PT program consisted of the Traditional Bobath approach (TBA) ${ }^{11}$, 
Rhythmic Movements ${ }^{12}$, Peto Method ${ }^{13}$. The OT program was based on games and exercises with objects (plasticine, geometric figures, balls, sticks, beads, etc.) in order to improve mobility and coordination of the upper limb and gain independence in performing ADLs. The RAT program consisted of interactive movement training during therapeutic programs with real-time tactile and audiovisual feedback, aiming to improve patient performance, namely to normalize muscle tone, increase ROM and speed reaction, reduce pain, improve coordination, visual recognition, and cognitive functions ${ }^{14}$. FES interventions were provided using a lightweight orthosis with five surface electrodes positioned on the forearm which sent electrical impulses to the muscles that control hand function.

The patients were assessed at admission and discharge. Data collection included:

- Sociodemographic information, such as sex, education, associated impairments;

- Movement performance in terms of coordination, respectively the percentage in which the patient can follow a pre-established pattern; assessed with a computerized system for the rehabilitation of the upper limb with neurological disorder, the result can range between 0 and 100\%;

- Wrist flexion using computerized goniometry;

- Three-fingered grasp strength using computerized dynamometry;

- Quantified assessment of the upper limb extremity functional limitation using Action Research Arm Test (ARAT) [15]; scores may range from 0-57 points, with a maximum score of 57 points indicating better performance ${ }^{16}$.

The statistical data processing was performed using the Statistical Package for the Social Sciences IBM SPSS Statistics 24. The data processing for the analysis of the potential correlations between the collected data followed-up two statistical indicators: statistical significance (p) and Pearson correlation coefficient (r) ${ }^{17,18}$. It was used paired sample t-test to determine the mean difference between two sets of observations - at admission and discharge - for coordination, wrist flexion, three-fingered grasp and ARAT score. Changes in variable scores were measured by means of $95 \%$ confidence interval (CI), respectively for statistical significance $\mathrm{p}<0.05$. The Pearson correlation coefficient is a measure of linear correlation between two sets of data. It returns a value between -1 and 1 , where 1 indicates a strong positive relationship, zero indicates no relati- onship at all, and - 1 indicates a strong negative relationship. The $r$ value indicates a moderate correlation if $0.40<\mathrm{r}<0.70$, a strong correlation if $0.70<\mathrm{r}<0.90$ and a very strong one if $r>0.90$.

\section{RESULTS}

The study group consisted of 90 patients, female and male, randomly divided into 2 groups (Control Group and FES Group) of 45 patients. Both groups had patients with associated impairments (visual, auditive, speech disorder, sleep disturbance, attention deficit, and coordination disorders). The groups characteristics are presented bellow in Table 1 .

Table 1. Characteristics of patients at baseline

\begin{tabular}{|c|c|c|}
\hline Outcomes & $\begin{array}{c}\text { FES group } \\
(\mathrm{n}=45)\end{array}$ & $\begin{array}{c}\text { Control group } \\
(\mathrm{n}=45)\end{array}$ \\
\hline Females/males (\%) & $27(60) / 18(40)$ & $9(20) / 36(80)$ \\
\hline $\begin{array}{l}\text { Associated impair- } \\
\text { ment (\%) }\end{array}$ & & \\
\hline Visual & $25(56)$ & $28(62)$ \\
\hline Auditive & $5(11)$ & $6(13)$ \\
\hline $\begin{array}{l}\text { Speech } \\
\text { disorder }\end{array}$ & $19(42)$ & $9(20)$ \\
\hline $\begin{array}{l}\text { Sleep } \\
\text { disturbance }\end{array}$ & $8(18)$ & $21(47)$ \\
\hline Attention & $22(49)$ & $25(56)$ \\
\hline Coordination & $33(73)$ & $6(13)$ \\
\hline Schooling (\%) & $2(4)$ & $39(87)$ \\
\hline $\begin{array}{l}\text { Special } \\
\text { education }\end{array}$ & $43(96)$ & \\
\hline $\begin{array}{l}\text { Inclusive } \\
\text { school }\end{array}$ & & \\
\hline
\end{tabular}

\section{Coordination}

A comparative analysis of the affected upper limb coordination was performed at admission (CBvP_int) and discharge (CBvP_ext). The result, with a maximum possible value of $100 \%$, indicates how accurately a pre-established trajectory was traced. To perform the comparison it was used the t-test to compare two pairs of samples.

- Null hypothesis: there are no differences between the two sets of measurements;

- Alternate hypothesis: there are differences between the two groups of variables that express coordination at admission and discharge. 
Table 2. Paired Samples Statistics (CBvP_int and CBvP_ext)

\begin{tabular}{|c|c|c|c|c|c|}
\hline \multicolumn{6}{|c|}{ Paired Samples Statistics for Control Group } \\
\hline \multicolumn{2}{|c|}{} & Mean & $\mathrm{N}$ & $\begin{array}{c}\text { Std. Devi- } \\
\text { ation }\end{array}$ & $\begin{array}{c}\text { Std. Error } \\
\text { Mean }\end{array}$ \\
\hline $\begin{array}{c}\text { Pair } \\
1\end{array}$ & CBvP_int & .8056 & 45 & .11494 & .01713 \\
\cline { 2 - 6 } & CBvP_ext & .8604 & 45 & .11443 & .01706 \\
\hline \multicolumn{7}{|c|}{ Paired Samples Statistics for FES Group } \\
\hline \multirow{2}{*}{ Pair 1 } & CBvP_int & .6802 & 45 & .21680 & .03232 \\
\cline { 2 - 7 } & CBvP_ext & .7622 & 45 & .18803 & .02803 \\
\hline
\end{tabular}

There is a lower value of coordination at admission compared to discharge, for both groups: Control Group CBvP_int $=0.8056$, compared to $\mathrm{CBvP}$ _ext $=$ 0.8604 and FES Group CBvP_int $=0.6802$, compared to CBvP_ext $=0.7622$.

Table 3. Paired Samples Correlations (CBvP_int and CBvP_ext)

\begin{tabular}{|c|c|c|c|c|}
\hline \multicolumn{5}{|c|}{ Paired Samples Correlations for Control Group } \\
\hline & & $\mathrm{N}$ & $\begin{array}{l}\text { Correla- } \\
\text { tion }\end{array}$ & Sig. \\
\hline $\begin{array}{c}\text { Pair } \\
1\end{array}$ & CBvP_int \& CBvP_ext & 45 & .868 & .000 \\
\hline \multicolumn{5}{|c|}{ Paired Samples Correlations for FES Group } \\
\hline & & $\mathrm{N}$ & $\begin{array}{l}\text { Correla- } \\
\text { tion }\end{array}$ & Sig. \\
\hline $\begin{array}{c}\text { Pair } \\
1\end{array}$ & CBvP_int \& CBvP_ext & 45 & .959 & .000 \\
\hline
\end{tabular}

Data analysis indicated a highly significant test $(\mathrm{p}<$ 0.001), a strong correlation between the two variables for Control Group $r=0.868$, and a very strong correlation for FES Group: $r=0.959$.

\section{Wrist Flexion}

It was assessed wrist flexion at admission (FPBv_int) and discharge (FPBv_ext).
Table 4. Paired Samples Statistics (FPBv_int and FPBv_ext)

\begin{tabular}{|c|c|c|c|c|c|}
\hline \multicolumn{6}{|c|}{ Paired Samples Statistics for Control Group } \\
\hline \multicolumn{2}{|c|}{} & Mean & N & $\begin{array}{c}\text { Std. De- } \\
\text { viation }\end{array}$ & $\begin{array}{c}\text { Std. Error } \\
\text { Mean }\end{array}$ \\
\hline \multirow{2}{*}{$\begin{array}{c}\text { Pair } \\
1\end{array}$} & FPBv_int & 40.9889 & 45 & 10.46082 & 1.55941 \\
\cline { 2 - 6 } & FPBv_ext & 49.7111 & 45 & 12.25871 & 1.82742 \\
\hline \multicolumn{5}{|c|}{ Paired Samples Statistics for FES Group } \\
\hline \multirow{2}{*}{$\begin{array}{c}\text { Pair } \\
1\end{array}$} & FPBv_int & 33.4222 & 45 & 19.42323 & 2.89544 \\
\cline { 2 - 6 } & FPBv_ext & 43.1711 & 45 & 20.26287 & 3.02061 \\
\hline
\end{tabular}

There is a lower value of wrist flexion at admission compared to discharge, for both groups: Control Group FPBv_int $=40.9889^{\circ}$, compared to FPBv_ext $=$ $49.7111^{\circ}$ and FES Group FPBv_int $=33.4222^{\circ}$, compared FPBv_ext $=43.1711^{\circ}$.

Table 5. Paired Samples Correlations (FPBv_int and FPBv_ext)

\begin{tabular}{|c|c|c|c|c|}
\hline \multicolumn{5}{|c|}{ Paired Samples Correlations for Control Group } \\
\hline & & $\mathrm{N}$ & $\begin{array}{c}\text { Correla- } \\
\text { tion }\end{array}$ & Sig. \\
\hline $\begin{array}{c}\text { Pair } \\
1\end{array}$ & FPBv_int \& FPBv_ext & 45 & .733 & .000 \\
\hline \multicolumn{5}{|c|}{ Paired Samples Correlations for FES Group } \\
\hline & & $\mathrm{N}$ & $\begin{array}{c}\text { Correla- } \\
\text { tion }\end{array}$ & Sig. \\
\hline $\begin{array}{c}\text { Pair } \\
1\end{array}$ & FPBv_int \& FPBv_ext & 45 & .927 & .000 \\
\hline
\end{tabular}

Data analysis indicated a highly significant test ( $\mathrm{p}<$ 0.001), a strong correlation between the two variables for Control Group $r=0.733$, and a very strong correlation for FES Group: $r=0.927$.

\section{Three-fingered grasp strength}

Due to its importance in performing ADLs, we considered it proper to assess the three-fingered grasp strength at admission (P3dgtBv_int) and discharge (P3dgtBv_ext). 
Benefits of Upper Limb Functional Electrical Stimulation in Children with Spastic Cerebral Palsy

Table 6. Paired Samples Statistics (P3dgtBv_int and P3dgtBv_ext)

\begin{tabular}{|c|c|c|c|c|c|}
\hline \multicolumn{6}{|c|}{ Paired Samples Statistics for Control Group } \\
\hline \multirow{2}{*}{ Pair } & $\begin{array}{c}\text { P3dgt- } \\
\text { Bv_int }\end{array}$ & 3.1689 & 45 & 1.04660 & .15602 \\
\cline { 2 - 6 } & $\begin{array}{c}\text { P3dgt- } \\
\text { Bv_ext }\end{array}$ & 3.8644 & 45 & 1.30247 & .19416 \\
\hline \multicolumn{7}{|c|}{$\begin{array}{c}\text { Std. Devi- } \\
\text { ation }\end{array}$} & $\begin{array}{c}\text { Std. Error } \\
\text { Mean }\end{array}$ \\
\hline \multirow{7}{*}{ Pair 1 } & Paired Samples Statistics for FES Group \\
\cline { 2 - 6 } & $\begin{array}{c}\text { P3dgt- } \\
\text { Bv_int }\end{array}$ & 1.7933 & 45 & .83132 & .12393 \\
\hline & $\begin{array}{c}\text { P3dgt- } \\
\text { Bv_ext }\end{array}$ & 2.8289 & 45 & .85110 & .12687 \\
\hline
\end{tabular}

Data indicated a lower value of three-fingered grasp strength at admission compared to discharge, for both groups: Control Group P3dgtBv_int = 3.1689, compared to P3dgtBv_ext $=3.8644$ and FES Group P3dgtBv_int $=1.7933$, compared to P3dgtBv_ext $=2.8289$.

Table 7. Paired Samples Correlations (P3dgtBv_int and P3dgtBv_ext)

\begin{tabular}{|c|c|c|c|c|}
\hline \multicolumn{5}{|c|}{ Paired Samples Correlations for Control Group } \\
\hline & & $\mathrm{N}$ & $\begin{array}{l}\text { Correla- } \\
\text { tion }\end{array}$ & Sig. \\
\hline $\begin{array}{l}\text { Pair } \\
1\end{array}$ & $\begin{array}{c}\text { P3dgtBv_int \& P3dgt- } \\
\text { Bv_ext }\end{array}$ & 45 & .884 & .000 \\
\hline \multicolumn{5}{|c|}{ Paired Samples Correlations for FES Group } \\
\hline & & $\mathrm{N}$ & $\begin{array}{l}\text { Correla- } \\
\text { tion }\end{array}$ & Sig. \\
\hline $\begin{array}{l}\text { Pair } \\
1\end{array}$ & $\begin{array}{c}\text { P3dgtBv_int \& P3dgt- } \\
\text { Bv_ext }\end{array}$ & 45 & .858 & .000 \\
\hline
\end{tabular}

Data analysis indicated a highly significant test $(\mathrm{p}<$ $0.001)$ and a strong correlation between the two variables, for both groups: Control Group $r=0.884$, and FES Group: $r=0.858$.

\section{Upper limb extremity functional limitation}

The comparative analysis of the motor activity limitation in the upper limb, at admission (ARAT_Bv_int) and discharge (ARAT_Bv_ext) provided information on the effectiveness of rehabilitation treatment.
Table 8. Paired Samples Statistics (ARAT_Bv_int and ARAT_Bv_ext)

\begin{tabular}{|c|c|c|c|c|c|}
\hline \multicolumn{6}{|c|}{ Paired Samples Statistics for Control Group } \\
\hline \multicolumn{2}{|c|}{} & Mean & $\mathrm{N}$ & $\begin{array}{c}\text { Std. } \\
\text { Deviation }\end{array}$ & $\begin{array}{c}\text { Std. Error } \\
\text { Mean }\end{array}$ \\
\hline $\begin{array}{c}\text { Pair } \\
1\end{array}$ & ARAT_Bv_int & 51.69 & 45 & 5.604 & .835 \\
\cline { 2 - 6 } & ARAT_Bv_ext & 54.02 & 45 & 5.025 & .749 \\
\hline \multirow{5}{*}{ Paired Samples Statistics for FES Group } \\
\hline \multirow{2}{*}{ Pair 1 } & ARAT_Bv_int & 36.00 & 45 & 17.485 & 2.607 \\
\cline { 2 - 6 } & ARAT_Bv_ext & 41.93 & 45 & 16.307 & 2.431 \\
\hline
\end{tabular}

Data indicated an improved upper limb functionality at discharge compared to admission, for both groups: Control Group ARAT_Bv_int $=51.69$, compared to ARAT_Bv_ext $=54.02$ and FES Group ARAT_Bv_ int $=36.00$, compared to ARAT_Bv_ext $=41.93$.

Table 9. Paired Samples Correlations (ARAT_Bv_int and ARAT_Bv_ext)

\begin{tabular}{|c|c|c|c|c|}
\hline \multicolumn{5}{|c|}{ Paired Samples Correlations for Control Group } \\
\hline & & $\mathrm{N}$ & Correlation & Sig. \\
\hline $\begin{array}{c}\text { Pair } \\
1\end{array}$ & ARAT_Bv_int \& ARAT_Bv_ext & 45 & .876 & .000 \\
\hline \multicolumn{5}{|c|}{ Paired Samples Correlations for FES Group } \\
\hline & & $\mathrm{N}$ & Correlation & Sig. \\
\hline $\begin{array}{c}\text { Pair } \\
1\end{array}$ & ARAT_Bv_int \& ARAT_Bv_ext & 45 & .964 & .000 \\
\hline
\end{tabular}

Data analysis indicated a highly significant test ( $\mathrm{p}<$ 0.001 ), a strong correlation between the two variables, for Control Group $r=0.884$, and a very strong one for FES Group: $r=0.858$. 


\section{DISCUSSIONS}

\section{Coordination}

Analyzing the upper limb coordination at admission and discharge, respectively the percentage in which the patient trace a pre-established trajectory, it was observed an $8.2 \%$ improvement in FES Group compared to 5.5\% in Control Group.

\section{Wrist flexion}

The ROM regarding wrist flexion in FES Group shown a $30 \%$ increase, from $33.4222^{\circ}$ at admission to $43.1711^{\circ}$ at discharge, while in the Control Group the increase was $20 \%$.

\section{Three-fingered grasp strength}

Three-fingered grasp strength increased by more than $50 \%$ in FES Group compared to $20 \%$ in Control Group.

\section{Upper limb extremity functional limitation}

The ARAT score indicates a decrease in upper limb functional limitation with more than $10 \%$ in the FES Group compared to $4 \%$ in the Control Group, relative to ARAT maximum value.

\section{CONCLUSIONS}

FES intervention was found to be an effective manner to improve motor performance, in terms of coordination, range of motion and three-fingered grasp strength, visibly reducing functional limitation and improving performance in activities of daily living.
Compliance with ethics requirements: The authors declare no conflict of interest regarding this article. The authors declare that all the procedures and experiments of this study respect the ethical standards in the Helsinki Declaration of 1975, as revised in 2008(5), as well as the national law. Informed consent was obtained from all the patients included in the study.

\section{ACKNOWLEDGMENT}

This study is part of the research carried out within the doctoral thesis bearing the title "Researches on Integrated Modes for the Development of Digital and Preparatory Abilities for Writing, in Children with Cerebral Palsy". The authors would like to thank the associate professor Liliana Padure for her support of the study, her involvement and her enthusiasm. 


\section{References}

1. P. Rosenbaum et al., "A report: the definition and classification of cerebral palsy April 2006," Dev Med Child Neurol Suppl, vol. 109, no. suppl 109, pp. 8-14, 2007.

2. M. Stavsky, O. Mor, S. A. Mastrolia, S. Greenbaum, N. G. Than, and O. Erez, "Cerebral palsy-trends in epidemiology and recent development in prenatal mechanisms of disease, treatment, and prevention," Front. Pediatr., vol. 5, no. February, pp. 1-10, 2017, doi: 10.3389/fped.2017.00021.

3. D. Reddihough, "Cerebral palsy in childhood," Aust. Fam. Physician, vol. 40, no. 4, pp. 192-196, 2011, doi: 10.1176/ ajp.115.9.845.

4. A. McGillivray, "General Movements Screening Guideline Women and Babies: General Movements Assessments (GMA) and other assessment modalities for prediction of cerebral palsy and adverse early neurodevelopment in high-risk infants," no. July 2011, 2011.

5. F. Fitoussi, A. Diop, N. Maurel, E. M. Laasel, B. Ilharreborde, and G. F. Penneçot, "Upper limb motion analysis in children with hemiplegic cerebral palsy: proximal kinematic changes after distal botulinum toxin or surgical treatments," J. Child. Orthop. vol. 5, no. 5, pp. 363-370, 2011.

6. D. Makki, J. Duodu, and M. Nixon, "Prevalence and pattern of upper limb involvement in cerebral palsy," J. Child. Orthop., vol. 8, no. 3, pp. 215-219, 2014.

7. N. Kapadia, B. Moineau, and M. R. Popovic, "Functional electrical stimulation therapy for retraining reaching and grasping after spinal cord injury and stroke," Front. Neurosci., vol. 14, p. 718, 2020.

8. E. Mash and D. Wolfe, "Intellectual Disability and Developmental Disorders," in Abnormal Child Psychologysychology, 7th ed., Boston: Cengage Learning, 2019, p. 672.

9. C. P. Charalambous, "Interrater reliability of a modified ashworth scale of muscle spasticity," Class. Pap. Orthop., pp. 415-417, 2014, doi: 10.1007/978-1-4471-5451-8_105
10. "Modified Ashworth Scale." https://www.strokengine.ca/en/ indepth/mashs_indepth/.

11. F. Behzadi, H. Noroozi, and M. Mohamadi, "The comparison of neurodevelopmental-bobath approach with occupational therapy home program on gross motor function of children with cerebral palsy," 2014.

12. A.-M. Johansson, E. Domellöf, and L. Rönnqvist, "Timing training in three children with diplegic cerebral palsy: short-and longterm effects on upper-limb movement organization and functioning," Front. Neurol., vol. 5, p. 38, 2014.

13. Q.-H. Zhang, D. Zheng, S.-Q. Liu, C.-Y. Zeng, Y.-F. Xu, and X.-Q. $\mathrm{Li}$, "Therapeutic effect of Peto method on the recovery of the motor function in children with cerebral palsy," Chinese J. Clin. Rehabil., vol. 8, pp. 2902-2903, May 2004.

14. M. Sandlund, E. Domellöf, H. Grip, L. Rönnqvist, and C. K. Häger, "Training of goal directed arm movements with motion interactive video games in children with cerebral palsy-a kinematic evaluation," Dev. Neurorehabil., vol. 17, no. 5, pp. 318-326, 2014.

15. E. S. Grattan, C. A. Velozo, E. R. Skidmore, S. J. Page, and M. L. Woodbury, "Interpreting Action Research Arm Test assessment scores to plan treatment. otjr (Thorofare NJ). 2019; 39 (1): 6473." Doi.

16. S. Figueiredo, "Action Research Arm Test (ARAT)." https://strokengine.ca/en/assessments/action-research-arm-test-arat/.

17. StatisticsSolutions, "Pearson's Correlation Coefficient." https:// www.statisticssolutions.com/pearsons-correlation-coefficient/ (accessed Sep. 30, 2020).

18. F. Williams and P. Monge, Reasoning with statistics: How to read quantitative research, 5th Editio. Orlando, Florida, USA: Harcourt College Publishers, 2001 